\title{
Metal-Organic Framework Nodes as Nearly Ideal Supports for Molecular Catalysts: NU-1000- and UiO-66-Supported Iridium Complexes
}

Dong Yang, ${ }^{\dagger}$ Samuel O. Odoh, ${ }^{\ddagger}$ Timothy C. Wang, ${ }^{\S}$ Omar K. Farha, ${ }^{\S}, \|$ Joseph T. Hupp, ${ }^{\S}$ Christopher J. Cramer, ${ }^{\ddagger}$ Laura Gagliardi, ${ }^{*}+\underset{*}{*}$ and Bruce C. Gates ${ }^{* \dagger}$

${ }^{\dagger}$ Department of Chemical Engineering \& Materials Science, University of California, Davis, California 95616, United States

${ }^{\ddagger}$ Department of Chemistry, Chemical Theory Center, and Supercomputing Institute, University of Minnesota, Minneapolis, Minnesota 55455-0431, United States

${ }^{\S}$ Department of Chemistry, Northwestern University, 2145 Sheridan Road, Evanston, Illinois 60208, United States

"Department of Chemistry, Faculty of Science, King Abdulaziz University, Jeddah 22254, Saudi Arabia

\section{Supporting Information}

ABSTRACT: Metal-organic frameworks with $\mathrm{Zr}_{6}$ nodes, $\mathrm{UiO}-66$ and NU-1000, were investigated as supports for $\operatorname{Ir}(\mathrm{CO})_{2}$ and $\operatorname{Ir}\left(\mathrm{C}_{2} \mathrm{H}_{4}\right)_{2}$ complexes. A single bonding site for the iridium is identified on the nodes of NU-1000, whereas two sites are identified on UiO66 , although at low iridium loadings only one site is occupied. Density functional theory calculations provide structural results that are in good agreement with infrared and $\mathrm{X}$-ray absorption fine-structure spectra. The reactivity of node-supported $\operatorname{Ir}(\mathrm{CO})_{2}$ with $\mathrm{C}_{2} \mathrm{H}_{4}$ and the catalytic activity and selectivity of the species initially present as $\operatorname{Ir}\left(\mathrm{C}_{2} \mathrm{H}_{4}\right)_{2}$ for ethylene hydrogenation and dimerization were investigated both experimentally and computationally and shown to be strongly influenced by the node.

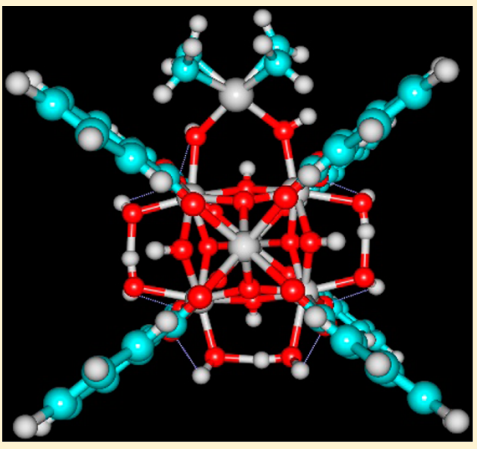

\section{INTRODUCTION}

Metal-organic frameworks (MOFs) are a class of crystalline and porous materials formed by coordination bonds between metal-containing nodes and organic linkers. ${ }^{1-3}$ MOFs that are stable at high temperatures are appealing but still littleinvestigated as catalyst supports, ${ }^{4-10}$ especially for transformations of gas-phase reactants. Several investigators have used the organic linkers of MOFs to anchor metal complexes used as catalysts. For example, Manna et al. ${ }^{11}$ prepared MOFs with $\mathrm{Fe}$ (II) and $\mathrm{Co}$ (II) salicylaldimine complexes as linkers, finding them to be highly active for 1-octene hydrogenation. Fei and Cohen ${ }^{12}$ modified the linkers of MOFs to form thiocatechol-functionalized sites for palladium centers that selectively catalyze the oxidative functionalization of aromatic $\mathrm{C}-\mathrm{H}$ bonds. Gonzalez et al. ${ }^{13}$ used an MOF with bipyridine sites in the linkers that reacted with $\operatorname{Ir}(\mathrm{COD})_{2} \mathrm{BF}_{4}$ (COD is 1,5cyclooctadiene) to give a catalyst for arene $\mathrm{C}-\mathrm{H}$ borylation. These catalysts are all comparable to organic polymersupported catalysts.

Alternatively, MOF nodes that resemble small pieces of metal oxides have been used as catalyst supports that are comparable to metal oxides and zeolites. Larabi and Quadrelli ${ }^{14}$ pointed out that the $\mathrm{OH}$ groups on such nodes provide sites for binding of organometallic catalyst precursors. For example, Nguyen et al. ${ }^{19}$ used defect sites in the zirconium oxide nodes of $\mathrm{UiO}-66$ as a support for a catalyst synthesized from vanadyl acetylacetonate to convert cyclohexene to benzene by oxidative dehydrogenation; this catalyst was used at temperatures up to $350{ }^{\circ} \mathrm{C}$, pointing to stability advantages of this class of MOF. Mondloch et al. ${ }^{16}$ also reported the use of such MOF nodes as supports for aluminum and zinc catalysts made by atomic layer deposition of gas-phase catalyst precursors.

Supported metal catalysts that are essentially molecular and structurally well-defined offer numerous advantages for fundamental understanding; such catalysts have been synthesized on the surfaces of zeolites and in prospect can be synthesized similarly on MOF nodes. ${ }^{17}$ We now report such catalysts: MOF node-supported metal complexes that are structurally well-defined, from the viewpoints of both the metal species and the support. We selected $\mathrm{Zr}_{6}$-based UiO-66 and NU-1000 frameworks because of their exceptional thermal stability and well-defined structures. ${ }^{16,18} \mathrm{UiO}-66$ is composed of $\left[\mathrm{Zr}_{6}\left(\mu_{3}-\mathrm{O}\right)_{4}\left(\mu_{3}-\mathrm{OH}\right)_{4}\right]^{12+}$ nodes, each linked to 12 carboxylates of terephthalate ligands to form tetrahedral and octahedral cages; however, there are many defects from missing linkers in this MOF, with the resulting otherwise open metal sites occupied by hydroxo ligands. ${ }^{18-28}$ The node topology of NU-1000 has been determined to be $\left[\mathrm{Zr}_{6}\left(\mu_{3}-\mathrm{O}\right)_{4}\left(\mu_{3^{-}}\right.\right.$ $\left.\mathrm{OH})_{4}(\mathrm{OH})_{4}\left(\mathrm{OH}_{2}\right)_{4}\right]^{8+}, 21$ and it is coordinated to eight

Received: March 20, 2015

Published: May 20, 2015 

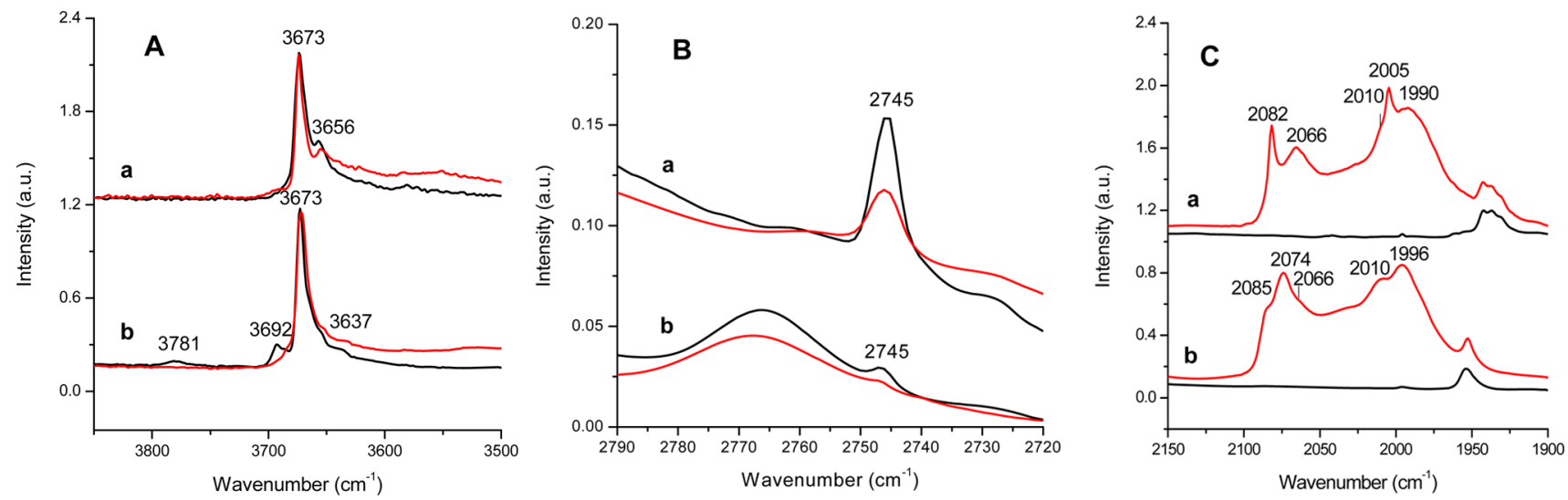

Figure 1. IR spectra in (A) $v_{\mathrm{OH}}$ region, (B) H-bonded $\mathrm{H}_{2} \mathrm{O}$ and $-\mathrm{OH}$ region and (C) $v_{\mathrm{CO}}$ region characterizing bare NU-1000, a, and bare UiO-66, $\mathrm{b}$, (black traces) and the samples formed by adsorption of $\operatorname{Ir}(\mathrm{CO})_{2}(\mathrm{acac})$ on them (red traces).

tetratopic linkers of 1,3,6,8-tetrakis( $p$-benzoic-acid)pyrene $\left(\mathrm{H}_{4} \mathrm{TBAPy}\right)$ to form triangular and hexagonal pores. We used $\operatorname{Ir}(\mathrm{CO})_{2}(\mathrm{acac})(\mathrm{acac}=$ acetylacetonate $)$ and $\operatorname{Ir}\left(\mathrm{C}_{2} \mathrm{H}_{4}\right)_{2}(\mathrm{acac})$ as precursors to react with functional groups such as $\mathrm{OH}$ on the nodes of NU-1000 and UiO-66, accompanied by removal of the acac ligands. ${ }^{17}$ The samples were characterized by infrared (IR) and extended X-ray absorption fine-structure (EXAFS) spectroscopies as well as density functional theory (DFT) calculations. Our results demonstrate the presence of bonding between the Ir species and node sites and determine their catalytic properties for conversion of ethylene in the presence of $\mathrm{H}_{2}$.

\section{EXPERIMENTAL SECTION}

2.1. Synthesis of UiO-66. $\mathrm{ZrCl}_{4}(0.080 \mathrm{~g}, 0.343 \mathrm{mmol})$ and 0.7 $\mathrm{mL}$ of acetic acid (modulator) were dissolved in $20 \mathrm{~mL}$ of DMF in a $100 \mathrm{~mL}$ Teflon-capped glass jar by using ultrasound for $5 \mathrm{~min}$. The linker precursor benzene-1,4-dicarboxylic acid $(0.057 \mathrm{~g}, 0.343 \mathrm{mmol})$ was then added into the solution and dissolved by ultrasound applied for about $5 \mathrm{~min}$. The jars were kept in an oven at $393 \mathrm{~K}$ under static conditions for $24 \mathrm{~h}$. White precipitates were produced, and they were isolated by centrifugation after cooling to room temperature. The solids were washed with DMF three times to remove unreacted precursors and with methanol six times to remove DMF. Then, the powder was dried at room temperature.

2.2. Synthesis of NU-1000. A sample consisting of $97 \mathrm{mg}$ of $\mathrm{ZrOCl}_{2} \cdot 8 \mathrm{H}_{2} \mathrm{O}(0.30 \mathrm{mmol})$ and $2700 \mathrm{mg}(22 \mathrm{mmol})$ of benzoic acid was mixed in $8 \mathrm{~mL}$ of DMF (in a 6 dram vial) and ultrasonically dissolved. The clear solution was incubated in an oven at $353 \mathrm{~K}$ for 1 h. After cooling to room temperature, $40 \mathrm{mg}(0.06 \mathrm{mmol})$ of $\mathrm{H}_{4} \mathrm{TBAPy}$ was added to this solution, and the mixture was sonicated for $20 \mathrm{~min}$. The yellow suspension was held in an oven at $353 \mathrm{~K}$ for 24 h. After cooling to room temperature, yellow polycrystalline material was isolated by filtration ( $35 \mathrm{mg}$ of activated material, $54 \%$ yield) and washed with DMF and subsequently activated with $\mathrm{HCl}$. Then, the solid was washed twice with DMF and six times with acetone. The powder was dried at room temperature.

2.3. Synthesis of $\operatorname{Ir}(\mathrm{CO})_{2}$ and $\operatorname{Ir}\left(\mathrm{C}_{2} \mathrm{H}_{4}\right)_{2}$ Supported on MOFs. Sample syntheses and handling were performed with the exclusion of moisture and air by use of a double-mainfold Schlenk vacuum line and an argon-atmosphere glovebox.

The precursor $\operatorname{Ir}(\mathrm{CO})_{2}(\mathrm{acac})$, with $98 \%$ purity, was purchased from Strem Chemicals, Inc. The precursor $\operatorname{Ir}\left(\mathrm{C}_{2} \mathrm{H}_{4}\right)_{2}$ (acac) was synthesized as described elsewhere; ${ }^{22}$ it has been characterized by X-ray diffraction crystallography and ${ }^{1} \mathrm{H}$ and ${ }^{13} \mathrm{C}$ NMR, Raman, and IR spectroscopies.

The supported iridium complex was prepared by bringing the precursor $\operatorname{Ir}(\mathrm{CO})_{2}(\mathrm{acac})$ or $\operatorname{Ir}\left(\mathrm{C}_{2} \mathrm{H}_{4}\right)_{2}$ (acac) $(36.2 \mathrm{mg}$ for a $10 \mathrm{wt} \%$ iridium loading or $3.6 \mathrm{mg}$ for a $1.0 \mathrm{wt} \%$ iridium loading) in contact with $200 \mathrm{mg}$ of activated MOF powder (UiO-66 or NU-1000 was activated under vacuum $\left(10^{-7}\right.$ Torr $)$ at 423 or $393 \mathrm{~K}$, respectively, for $24 \mathrm{~h}$ before use) in a Schlenk flask and slurried in $40 \mathrm{~mL}$ of dried $n$ pentane (Fisher, 99\%) at room temperature. After $4 \mathrm{~h}$, the solvent was removed by evacuation for a day so that all the iridium remained in the MOF. The resultant solids, containing 10 or $1.0 \mathrm{wt} \%$ iridium, were stored in the argon-filled glovebox. The iridium loadings were inferred from the conditions of the syntheses, whereby all of the added iridium remained in the MOF.

2.4. Infrared Spectroscopy. A Bruker IFS 66v/S spectrometer with a spectral resolution of $2 \mathrm{~cm}^{-1}$ was used to collect transmission IR spectra of power samples. Approximately $30 \mathrm{mg}$ of solid sample inside a glovebox was pressed into a thin wafer and loaded into a cell that served as a flow reactor (In-situ Research Institute, Inc., South Bend, IN). The cell was sealed and connected to a flow system that allowed recording of spectra while the reactant gases flowed through the cell at reaction temperature. Each spectrum is the average of 64 scans.

2.5. X-ray Absorption Spectroscopy. X-ray absorption spectra were recorded at X-ray beamline 4-1 at the Stanford Synchrotron Radiation Lightsource (SSRL). The storage ring electron energy and ring current were $3 \mathrm{GeV}$ and $300 \mathrm{~mA}$, respectively. A double-crystal $\mathrm{Si}(220)$ monochromator was detuned by $20-25 \%$ at the $\operatorname{Ir} L_{\mathrm{III}}$ edge to minimize the effects of higher harmonics in the X-ray beam.

2.6. Catalytic Reaction Rates. Ethylene hydrogenation catalysis was carried out in a conventional laboratory once-through tubular plug-flow reactor at $298 \mathrm{~K}$ and 1 bar. The catalyst $(10-50 \mathrm{mg})$ was mixed with $10 \mathrm{~g}$ of inert, nonporous $\alpha-\mathrm{Al}_{2} \mathrm{O}_{3}$ and loaded into the reactor in the argon-filled glovebox. The feed partial pressures were $100 \mathrm{mbar}$ of $\mathrm{C}_{2} \mathrm{H}_{4}, 200 \mathrm{mbar}$ of $\mathrm{H}_{2}$, and $700 \mathrm{mbar}$ of $\mathrm{He}$, with a total flow rate of $100 \mathrm{~mL}(\mathrm{NTP}) / \mathrm{min}$. Products were analyzed with an online Agilent 6890 gas chromatograph. The ethylene conversions were $<5 \%$, and the reactor was well approximated as differential, determining reaction rates directly.

2.7. Computational Methods. Density functional theory (DFT) calculations were performed on neutral cluster models with the M06$\mathrm{L}^{23}$ density functional as implemented in the Gaussian 09 software package. In this software package, we used ultrafine grids ( 99 radial nodes and 590 angular nodes for $\mathrm{C}, \mathrm{H}$, and $\mathrm{O}$ atoms, but 199 radial nodes and 974 angular nodes for $\mathrm{Zr}$ and $\mathrm{Ir}$ atoms) for numerical integrations. The def2-svp basis set was used for the $\mathrm{C}, \mathrm{H}$, and $\mathrm{O}$ atoms, whereas the def2-tzvpp ${ }^{24-26}$ basis set and associated effective core potential were employed for $\mathrm{Zr}$ and Ir atoms. The positions of all atoms, with the exceptions of the atoms in the aryl organic linkers, were optimized. Vibrational frequency analyses were carried out to confirm the nature of the stationary points found after each geometry optimization. The geometry optimizations and vibrational frequency analyses were carried out for the samples in the gas phase as well as in $n$-pentane. The polarizable continuum model $\left(\mathrm{PCM}^{27}\right)$ was used to account for solvation effects for the calculations carried out with the samples in $n$-pentane. 
The cluster models were constructed from periodic unit cells of NU-1000 and UiO-66 optimized with the generalized-gradient approximation $\mathrm{PBE}^{28}$ density functional while using plane-wave basis sets within the projector-augmented wave approach as implemented in the Vienna Ab Initio Simulation Package $\left(\mathrm{VASP}^{29-32}\right.$ ). In these periodic calculations, we used a plane-wave kinetic energy cutoff of 520 $\mathrm{eV}$, a convergence criterion of $0.05 \mathrm{eV} / \AA ̊$ for atomic positions, and an automatically generated gamma-centered Monkhorst-Pack k-point grid.

The procedure for generating the cluster models from the optimized periodic structure of NU-1000 has been described. ${ }^{21}$ Briefly, the first coordination sphere of the $\mathrm{Zr}_{6}$-metalate node was extracted from the periodic structure while truncating the TPAPy ${ }^{4-}$ linkers to benzoate groups. A two-step protocol was then used for optimizing the resulting clusters. First, we optimized the positions of the aromatic $\mathrm{H}$ atoms while fixing all other atoms. Second, the $\mathrm{C}_{6} \mathrm{H}_{5}$ units of the benzoate groups were held fixed, whereas the positions of all other atoms were optimized. A similar procedure was used for UiO66. However, the linkers in its periodic model were truncated to acetate groups to speed up the computations.

\section{RESULTS AND DISCUSSION}

3.1. $\operatorname{Ir}(\mathrm{CO})_{2}$ Complexes Supported on Nodes of NU1000 and of UiO-66. $\operatorname{Ir}(\mathrm{CO})_{2}$ (acac) in $n$-pentane solution reacted with NU-1000 nodes, removing the protons in hydrogen-bonded $\mathrm{H}_{2} \mathrm{O} / \mathrm{OH}$ groups, ${ }^{21}$ as shown by the decreased intensities of the $2745 \mathrm{~cm}^{-1}$ band in the IR spectra (Figure 1B) and forming chemisorbed species assigned on the basis of new IR bands at 2066 and $1990 \mathrm{~cm}^{-1}$ as iridium gemdicarbonyls bonded to two ligands inferred to be oxygen atoms also coordinated to the $\mathrm{Zr}_{6}$ node (Figure 2). The iridium
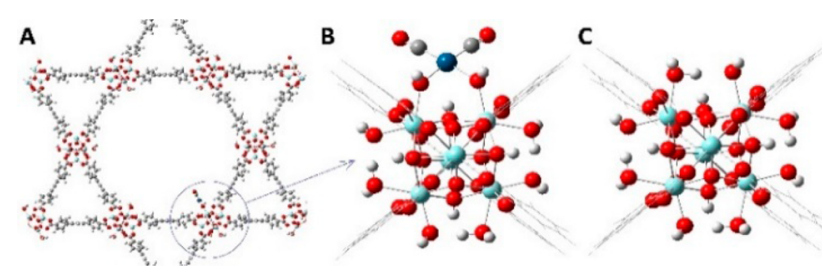

Figure 2. $\operatorname{Ir}(\mathrm{CO})_{2}$ deposited onto the $\mathrm{Zr}_{6}$ nodes of NU-1000. (A) Location of the iridium complex in a periodic crystal of NU-1000. (B) Expanded view of the iridium complex at the $\mathrm{Zr}_{6}$ node. (C) Same site in pristine NU-1000 prior to $\operatorname{Ir}(\mathrm{CO})_{2}$ complexation.

loading was $10.0 \mathrm{wt} \%$, corresponding to nearly one Ir atom per node. The $v_{\mathrm{CO}}$ bands shifted to 2017 and $1943 \mathrm{~cm}^{-1}$ when the sample was brought in contact with ${ }^{13} \mathrm{CO}$ at room temperature, confirming the identification (Figure S2 and Table S1, Supporting Information). EXAFS parameters measured at the Ir $L_{\text {III }}$ edge confirm the structure, with the coordination numbers and interatomic distances shown in Table 1. This structure closely matches that of $\operatorname{Ir}(\mathrm{CO})_{2}$ on a zeolite. ${ }^{33-36}$

$\operatorname{Ir}(\mathrm{CO})_{2}(\mathrm{acac})$ in $n$-pentane solution reacted similarly with UiO-66 nodes, but, in contrast to NU-1000, UiO-66 reacted with $\operatorname{Ir}(\mathrm{CO})_{2}(\mathrm{acac})$ to give two chemisorbed species, identified on the basis of IR spectroscopy, with a pair of $v_{\mathrm{CO}}$ bands at 2074 and $1996 \mathrm{~cm}^{-1}$, and a band at $2066 \mathrm{~cm}^{-1}$. Both bands characterizing non-hydrogen-bonded node $\mathrm{OH}$ groups, at 3781 and $3692 \mathrm{~cm}^{-1}$ (Figure 1A, Table S2), and hydrogen-bonded node $\mathrm{H}_{2} \mathrm{O} / \mathrm{OH}$ species, at $2745 \mathrm{~cm}^{-1}$ (Figure $1 \mathrm{~B}$ ), decreased in intensity as a result of the chemisorption reaction, indicating the participation of these groups, in this case associated with site defects (see below). Correspondingly, the pore volumes of the MOFs decreased (section S4, Supporting Information).
Table 1. EXAFS and Calculated DFT Structural Parameters of $\operatorname{Ir}(\mathrm{CO})_{2}$ Supported on NU-1000 $\mathrm{Zr}_{6}$ Nodes $^{a}$

\begin{tabular}{|c|c|c|c|c|c|}
\hline \multicolumn{5}{|c|}{ EXAFS } & DFT \\
\hline shell & $10^{3} \times \Delta \sigma^{2}\left(\AA^{2}\right)$ & $\Delta E_{0}(\mathrm{eV})$ & $N$ & $R(\AA)$ & $R(\AA)$ \\
\hline $\mathrm{Ir}-\mathrm{O}_{\mathrm{t}}$ & 5.4 & -5.2 & 2.0 & 2.05 & 2.11 \\
\hline $\mathrm{Ir}-\mathrm{C}_{\mathrm{CO}}$ & 14.6 & -5.9 & 2.1 & 1.97 & 1.83 \\
\hline $\mathrm{Ir}-\mathrm{O}_{\mathrm{CO}}$ & 14.5 & 7.4 & 2.1 & 2.99 & 2.98 \\
\hline $\mathrm{Ir}-\mathrm{O}_{\mathrm{b}}$ & 6.8 & -5.6 & 1.9 & 3.13 & 3.39 \\
\hline $\mathrm{Ir}-\mathrm{Zr}$ & 14.2 & -0.7 & 2.0 & 3.55 & 3.72 \\
\hline
\end{tabular}

${ }^{a}$ Notation: $\mathrm{O}_{\mathrm{t}}, \mathrm{O}$ atoms of terminal $-\mathrm{OH}$ groups on $\mathrm{Zr}_{6}$ node; $\mathrm{C}_{\mathrm{CO}}$, carbonyl carbon; $\mathrm{O}_{\mathrm{CO}}$, carbonyl oxygen; $\mathrm{O}_{\mathrm{b}}, \mathrm{O}$ in bridging $\mu_{3}-\mathrm{OH}$ or $\mu_{3}-\mathrm{O}$ group on $\mathrm{Zr}_{6}$ node; $N$, coordination number; $R$, distance between absorber and backscatterer atoms; $\Delta \sigma^{2}$, disorder term; $\Delta E_{0}$, inner potential correction. Estimated EXAFS error bounds: $N, \pm 20 \%$; $R, \pm 0.02 \AA ; \Delta \sigma^{2}, \pm 20 \%$; $\Delta E_{0}, \pm 20 \%$ (Errors characterizing the $\mathrm{Ir}-\mathrm{Zr}$ contribution are greater.); fit range: $3.87<k$ (wave vector) $<13.61$ $\AA^{-1} ; 0.5<R<4 \AA$; goodness of fit value $=3.5$.

At the high loading of $10 \mathrm{wt} \%$ iridium, we also detected physisorbed $\operatorname{Ir}(\mathrm{CO})_{2}$ (acac) on each MOF, as shown by the IR bands at 2085 and $2010 \mathrm{~cm}^{-1}$ (Figure 1C), which are close in frequency to those characterizing $\operatorname{Ir}(\mathrm{CO})_{2}(\mathrm{acac})$ in $n$-hexane solution. ${ }^{37}$ Because the pore aperture of UiO-66 $(\sim 6 \AA)^{18}$ is barely greater than the narrowest dimension of the precursor $\left(\sim 4 \times 6 \AA^{2}\right)$, we infer that the supported iridium species were present preferentially near the external UiO-66 particle surfaces. ${ }^{38,39}$ The $2010 \mathrm{~cm}^{-1}$ band is also evident in the spectrum of the NU-1000-supported species, and it disappeared after $8 \mathrm{~h}$ of contact of the precursor with this MOF, during which time two sharp bands at 2082 and $2005 \mathrm{~cm}^{-1}$ (also assigned to physisorbed $\operatorname{Ir}(\mathrm{CO})_{2}$ (acac) Figure 1C) decreased in intensity and then disappeared after $20 \mathrm{~h}$ (Figure S5). Because these disappeared slowly, we suggest that they were indicative of iridium-containing species on the internal NU-1000 surface and that their removal was slowed by their diffusion in the narrow pores.

To determine the structures of the iridium-supporting sites, we performed DFT calculations characterizing the structure of iridium complexes on neutral cluster models of NU-1000. The calculations for NU-1000 show that the most stable iridium complexes are situated in the MOF channels, with the metal atom replacing the proton in a terminal $\mathrm{OH}_{2}$ group that otherwise bridges to an adjacent terminal $\mathrm{OH}$ group on the node (Figure 2). This result is consistent with the experimental observation showing a decreased intensity of the H-bonded $\mathrm{H}_{2} \mathrm{O}$ and $-\mathrm{OH}$ band at $2745 \mathrm{~cm}^{-1}$ after reaction of $\operatorname{Ir}(\mathrm{CO})_{2}(\mathrm{acac})$ with NU-1000 (Figure 1B). To confirm the assignment of the IR band at $2745 \mathrm{~cm}^{-1}$, we note that DFT predicts that this vibration will be found at approximately 2851 and $2875 \mathrm{~cm}^{-1}$. Application of a scaling factor of 0.956 changes these calculated values to 2726 and $2749 \mathrm{~cm}^{-1}$, in good agreement with the experiment. The choice of this scaling factor is discussed below.

The calculated structural parameters for this binding mode, Figure 2, are compared with EXAFS data in Table 1. Agreement is generally good, although the distances between the $\mathrm{Ir}$ atoms and bridging $\mathrm{O}$ or $\mathrm{Zr}$ atoms of the node are overestimated by $0.2-0.3 \AA$, consistent with results of analogous combined DFT/EXAFS ${ }^{40,41}$ investigations. The calculated $v_{\mathrm{CO}}$ bands of this binding mode are 2157 and $2085 \mathrm{~cm}^{-1}$. Alecu et al. ${ }^{42}$ determined scale factors of $0.951-$ 0.958 for fundamental vibrational frequencies obtained with 
various M06-L model chemistries; a scaling factor of 0.956 brings the calculated frequencies of the two $v_{\mathrm{CO}}$ bands to 2062 and $1993 \mathrm{~cm}^{-1}$, both within $4 \mathrm{~cm}^{-1}$ of experiment, Figure 1C. The calculated separation of the bands $\left(69 \mathrm{~cm}^{-1}\right.$ after scaling) matches experiment $\left(76 \mathrm{~cm}^{-1}\right)$ to within $10 \%$.

On UiO-66 (Figure $3 \mathrm{~A}-\mathrm{C}$ ), there are three possible types of defects that can be created by the loss of an organic linker
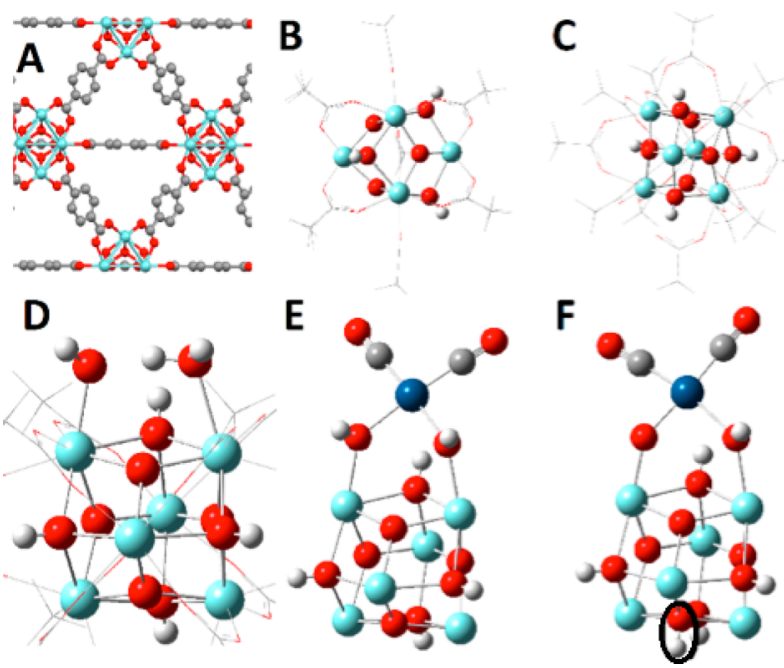

Figure 3. (A) Periodic structure showing the pore channels of UiO-66. (B) Model cluster representing the $\mathrm{Zr}_{6}$ node. (C) Same model cluster rotated $90 \mathrm{deg}$ about the horizontal axis. (D) Ligand defect with terminal $-\mathrm{OH}$ and $\mathrm{OH}_{2}$ groups replacing a missing linker. (E) Site 1 complexation of $\operatorname{Ir}(\mathrm{CO})_{2}$. (F) Site 2 complexation of $\operatorname{Ir}(\mathrm{CO})_{2}$ (with "extra" $\mu_{3}-\mathrm{OH}$ group circled in black).

(section 8, Supporting Information). The most stable defect is shown in Figure 3D and offers a binding site (site 1) similar to that of NU-1000 (Figure 2C). The decrease of the hydrogenbonded $\mathrm{H}_{2} \mathrm{O}$ and $-\mathrm{OH}$ band at $2745 \mathrm{~cm}^{-1}$ (Figure 1B) indicates the reaction of $\operatorname{Ir}(\mathrm{CO})_{2}(\mathrm{acac})$ with site 1 on UiO-66. After bonding of $\operatorname{Ir}(\mathrm{CO})_{2}$ to this defect, Figure 3E, we calculate unscaled $v_{\mathrm{CO}}$ bands of 2165 and $2090 \mathrm{~cm}^{-1}$, very similar to those obtained for NU-1000 and corresponding to the lowerfrequency pair observed experimentally, Figure 1C. The structural parameters of this complex are very similar to those in Table 1 for NU-1000. At the M06-L level, formation of $\operatorname{Ir}(\mathrm{CO})_{2}$ supported at site 1 from $\operatorname{Ir}(\mathrm{CO})_{2}(\mathrm{acac})$ is calculated to be exoergic by $-4.3 \mathrm{kcal} / \mathrm{mol}$.

After consideration of a number of possibilities and an assessment of their energies, we assign the second site (site 2) for adsorption of $\operatorname{Ir}(\mathrm{CO})_{2}$ on $\mathrm{UiO}-66$ as shown in Figure 3F. In this case, a proton has migrated from one coordinating $\mathrm{OH}$ group to a $\mu_{3}-\mathrm{O}$ oxo group (creating an additional $\mu_{3}-\mathrm{OH}$ group, Figure $3 \mathrm{~F}$ ). The above-mentioned non-hydrogenbonded $\mathrm{OH}$ bands at 3781 and $3692 \mathrm{~cm}^{-1}$ are calculated to be the hydroxyl groups of site 2 (Table S2). They disappeared after reaction of $\operatorname{Ir}(\mathrm{CO})_{2}(\mathrm{acac})$ with these sites. These bands were calculated as being at approximately 3947 and $3875 \mathrm{~cm}^{-1}$, respectively, from our DFT calculations. Again, application of the scaling factor brings good agreement with empirical data ( 3773 and $3704 \mathrm{~cm}^{-1}$, respectively).

The unscaled calculated $v_{\mathrm{CO}}$ bands for the resulting $\operatorname{Ir}(\mathrm{CO})_{2}$ complex at site 2 are 2173 and $2104 \mathrm{~cm}^{-1}$, corresponding to the higher-frequency pair observed experimentally, Figure 1C. When the scaling factor of 0.956 is applied to the four computed values (giving 2070 and $1998 \mathrm{~cm}^{-1}$ for site 1 and 2077 and $2011 \mathrm{~cm}^{-1}$ for site 2), the mean unsigned error compared to experimental values is $8 \mathrm{~cm}^{-1}$, offering good support for these structural assignments. We note that the higher carbonyl stretching frequencies associated with site 2 suggest less back-donation from Ir into acceptor $\pi^{*}$ CO orbitals. Consistent with this analysis, calculated partial atomic charges on the Ir center are more positive in site 2 (Hirshfeld: ${ }^{43} 0.29$; Mulliken: ${ }^{44} 0.51$ ) than in site 1 (Hirshfeld: 0.17; Mulliken: 0.36).

We emphasize that $\operatorname{Ir}(\mathrm{CO})_{2}$ (acac) did not react with the bridging $\mu_{3}-\mathrm{OH}$ groups on the $\mathrm{Zr}_{6}$ nodes, characterized by the IR band at $3673 \mathrm{~cm}^{-1}$, as indicated by the lack of change of this band, either on NU-1000 or UiO-66, after anchoring of the iridium precursor (Figure 1A). DFT calculations confirm that reaction of $\operatorname{Ir}(\mathrm{CO})_{2}$ groups with the bridging $\mu_{3}-\mathrm{OH}$ groups found at defects in UiO-66 is endoergic by about $28 \mathrm{kcal} / \mathrm{mol}$, a value that is in marked contrast to the calculated reaction energies for the adsorption of $\operatorname{Ir}(\mathrm{CO})_{2}$ on site $1(-4.3 \mathrm{kcal} /$ $\mathrm{mol})$ and site $2(1.2 \mathrm{kcal} / \mathrm{mol})$.

$\operatorname{Ir}(\mathrm{CO})_{2}$ supported on the MOFs, when treated with flowing $\mathrm{C}_{2} \mathrm{H}_{4}$, underwent a limited ligand exchange reaction, sometimes leading to replacement of one $\mathrm{CO}$ by $\mathrm{C}_{2} \mathrm{H}_{4}$ but only for site 2 in the UiO-66 complex. In that case, a new band at $2020 \mathrm{~cm}^{-1}$ was observed and assigned to $\operatorname{Ir}(\mathrm{CO})\left(\mathrm{C}_{2} \mathrm{H}_{4}\right)$ (Figure 4).

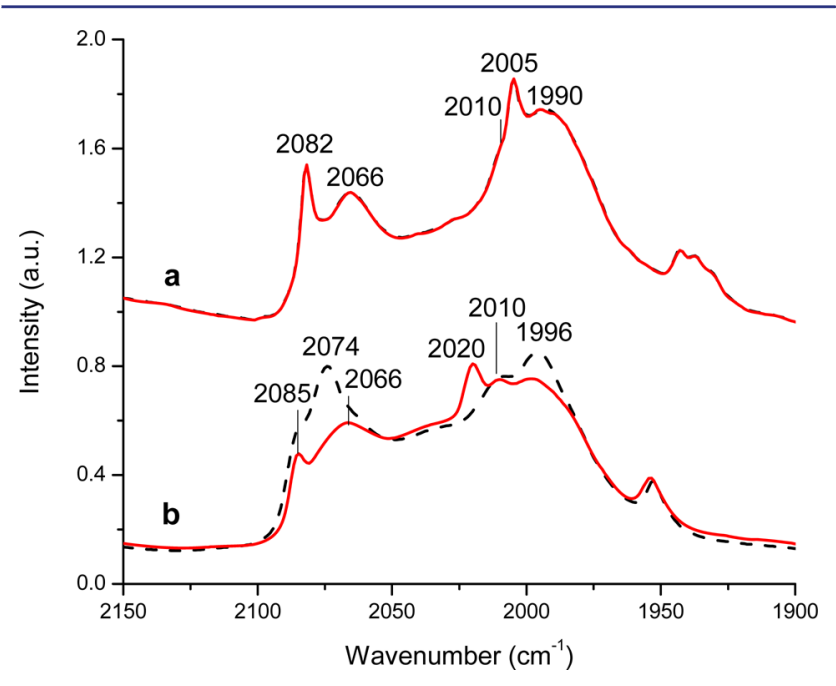

Figure 4. IR spectra in the $v_{\mathrm{CO}}$ region characterizing in the sample initially formed by the chemisorption of $\operatorname{Ir}(\mathrm{CO})_{2}(\mathrm{acac})$ on NU-1000 (a) and UiO-66 (b) as initially present (dashed black traces) and after exposure to flowing ethylene at $298 \mathrm{~K}$ and 1 bar for $20 \mathrm{~min}$ (red traces).

3.2. $\operatorname{Ir}\left(\mathrm{C}_{2} \mathrm{H}_{4}\right)_{2}$ Complexes Supported on the Nodes of NU-1000 and UiO-66. Supported $\operatorname{Ir}\left(\mathrm{C}_{2} \mathrm{H}_{4}\right)_{2}$ complexes were prepared alternatively from reactions with pristine MOFs employing precursor $\operatorname{Ir}\left(\mathrm{C}_{2} \mathrm{H}_{4}\right)_{2}$ (acac) in a fashion analogous to that for $\operatorname{Ir}(\mathrm{CO})_{2}(\mathrm{acac})$. IR data (Figures S6 and S7, Supporting Information) indicate that $\operatorname{Ir}\left(\mathrm{C}_{2} \mathrm{H}_{4}\right)_{2}$ also adsorbs onto the nodes, again with single iridium complexes on NU-1000 and a mixture on UiO-66. We sought to prepare supported catalysts dominated by the species analogous to those characterized above, rather than more complex mixtures, by using low loadings of iridium on the supports (1 wt \%). At this loading, IR spectra (Figure 5) are consistent with the supports being nearly ideal, and these well-defined samples were tested as 


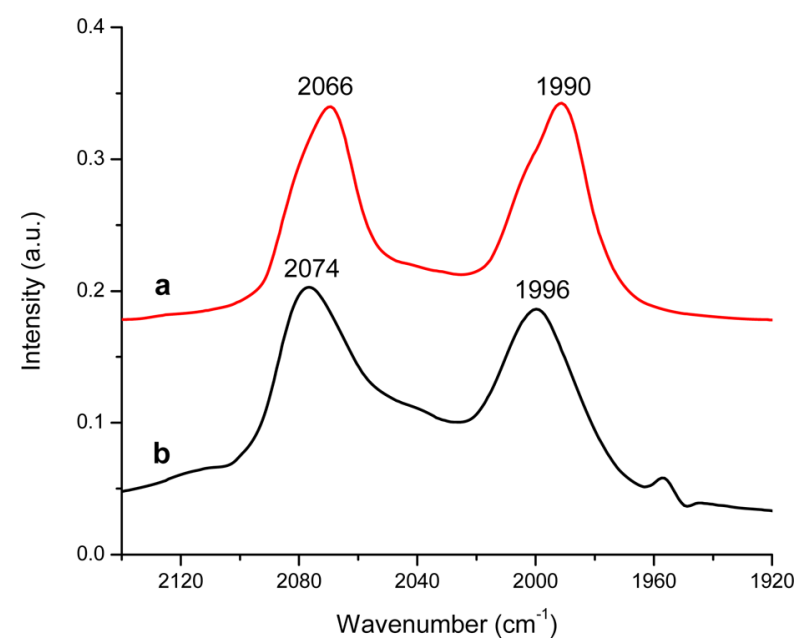

Figure 5. IR spectra in the $v_{\mathrm{CO}}$ region characterizing the sample initially formed by the adsorption of $\operatorname{Ir}(\mathrm{C} 2 \mathrm{H} 4)_{2}(\mathrm{acac})$ (with iridium loading $1 \%$ ) on NU-1000 (a, red trace) and UiO-66 (b, black trace) after exposure to flowing $\mathrm{CO} 10 \% / \mathrm{He}$ at $298 \mathrm{~K}$ and 1 bar for $2 \mathrm{~min}$.

catalysts for ethylene conversion in a once-through flow reactor in the presence of $\mathrm{H}_{2}$ at $300 \mathrm{~K}$ and 1 bar.

The supported $\operatorname{Ir}\left(\mathrm{C}_{2} \mathrm{H}_{4}\right)_{2}$ complexes were found to be precatalysts for ethylene hydrogenation accompanied by slight ethylene dimerization (Table 2 ), with the activity and selectivity

Table 2. Catalytic Activities of MOF Node-Supported Iridium Complexes for Hydrogenation and Dimerization of Ethylene in a Flow Reactor at $298 \mathrm{~K}$ and 1 bar $^{a}$

\begin{tabular}{|c|c|c|c|c|c|c|c|}
\hline \multirow[b]{3}{*}{ support $^{b}$} & \multirow[b]{3}{*}{$\begin{array}{l}\text { TOF } \\
\left(\mathrm{s}^{-1}\right)^{c}\end{array}$} & \multicolumn{6}{|c|}{$\begin{array}{l}\text { selectivity under differential conversion conditions } \\
\qquad(\mathrm{mol} \%)\end{array}$} \\
\hline & & \multirow[b]{2}{*}{ ethane } & \multirow[b]{2}{*}{ butane } & \multirow[b]{2}{*}{ butene } & \multicolumn{3}{|c|}{ butene isomers } \\
\hline & & & & & $\begin{array}{l}\text { trans-2- } \\
\text { butene }\end{array}$ & $\begin{array}{c}1- \\
\text { butene }\end{array}$ & $\begin{array}{l}\text { cis-2- } \\
\text { butene }\end{array}$ \\
\hline NU-1000 & 0.010 & 99.5 & 0 & 0.5 & 0 & 0.5 & 0 \\
\hline $\mathrm{UiO}-66$ & 0.017 & 98.5 & 0.4 & 1.1 & 0.2 & 0.8 & 0.1 \\
\hline
\end{tabular}

${ }^{a}$ There was no detectable reaction in the absence of the catalyst under our conditions, and the MOF alone was catalytically inactive. ${ }^{b}$ Support for catalyst initially incorporating node-anchored $\operatorname{Ir}\left(\mathrm{C}_{2} \mathrm{H}_{4}\right)_{2} \cdot{ }^{c}$ Turnover frequency determined from $\mathrm{C}_{2} \mathrm{H}_{4}$ conversions $<5 \%$; catalyst mass $=$ $10-50 \mathrm{mg}$; feed partial pressures $=100 \mathrm{mbar}_{2} \mathrm{H}_{4}, 200 \mathrm{mbar}_{2}$, and $700 \mathrm{mbar} \mathrm{He}$; total flow rate $=100 \mathrm{~mL}(\mathrm{NTP}) / \mathrm{min}$.

both depending on which MOF was used as the support. As noted above, the iridium center of site 2 is more electropositive (or electrophilic) than that of site 1 in the $\operatorname{Ir}(\mathrm{CO})_{2}$ complexes. This pattern extends to the corresponding $\operatorname{Ir}\left(\mathrm{C}_{2} \mathrm{H}_{4}\right)_{2}, \operatorname{Ir}(\mathrm{CO})$ $\left(\mathrm{C}_{2} \mathrm{H}_{4}\right), \operatorname{Ir}(\mathrm{CO})\left(\mathrm{C}_{2} \mathrm{H}_{4}\right)\left(\mathrm{H}_{2}\right)$, and $\operatorname{Ir}\left(\mathrm{C}_{2} \mathrm{H}_{4}\right)_{2}\left(\mathrm{H}_{2}\right)$ species as well. Thus, the nature of the MOF support affects the transition states and activation energies for the various catalytic reactions. In Figure 6, for instance, the calculated barriers for ethylene dimerization catalysis via an intermediate metallacycle are lower for site 2 of UiO-66 than for site 1 . Insofar as the NU-1000 catalytic site is analogous to the UiO-66 site 1, Figure 6, this result rationalizes the increased dimerization selectivity observed for UiO-66 and is also consistent with IR data suggesting that site 2 dominates the catalytic reactivity of $\mathrm{UiO}$ 66.

Competing reaction mechanisms for ethylene dimerization were explored; the one reported in Figure 6 was found to be energetically the most favorable. The pathway for ethylene

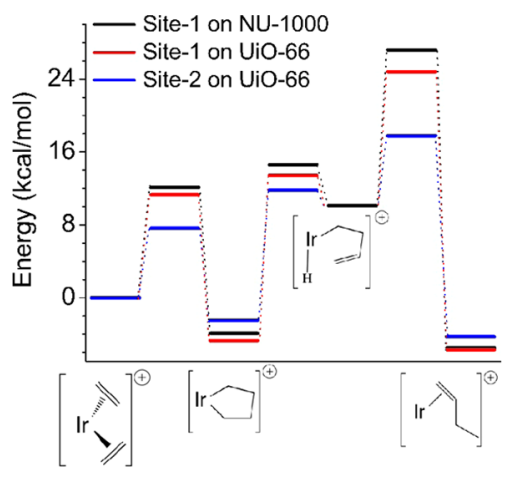

Figure 6. Calculated pathway for the dimerization of ethylene to 1butene at sites 1 and 2 for $\operatorname{Ir}\left(\mathrm{C}_{2} \mathrm{H}_{4}\right)_{2}$ on UiO-66 and NU-1000 at M06-L level. (MOF nodes as counteranions are implicit.) More details are available in section S8 of the Supporting Information.

hydrogenation was also investigated, and the results show that hydrogenation is favored over dimerization because of the lower calculated barriers $(2-12 \mathrm{kcal} / \mathrm{mol}$ for hydrogenation, section S8, Supporting Information, versus 8-19 kcal/mol for dimerization, Figure 6) and the weak adsorption of ethane on the iridium sites (relative to alkenes), which favors desorption of this product, Table 2 .

We probed the used catalysts (after $1 \mathrm{~h}$ of continuous ethylene hydrogenation) with a pulse of $\mathrm{CO}$ introduced into the feed stream. The results (Figure S8, Supporting Information) indicate the formation of the iridium gemdicarbonyl bands essentially matching those of the fresh catalyst, thereby demonstrating the stability of the mononuclear iridium complexes under catalytic reaction conditions.

\section{CONCLUSIONS}

The nodes of NU-1000 and UiO-66 MOFs are essentially molecular catalyst supports upon which highly uniform catalytic metal complexes can be chemisorbed. These are among the simplest and best-defined of any supported metal species, constituting, we infer, an emerging class of materials that may offer broad opportunities for discovery of new catalysts guided by theory. We may expect high selectivities associated with the uniformity of the catalytic species and high stabilities when combinations of metals and MOFs are appropriately chosen.

\section{ASSOCIATED CONTENT}

Supporting Information

Experimental and computational details as reported in the text. The Supporting Information is available free of charge on the ACS Publications website at DOI: 10.1021/jacs.5b02956.

\section{AUTHOR INFORMATION}

\section{Corresponding Authors}

*gagliard@umn.edu

*bcgates@ucdavis.edu

\section{Notes}

The authors declare no competing financial interest.

\section{ACKNOWLEDGMENTS}

This work was supported as part of the Inorganometallic Catalyst Design Center, an Energy Frontier Research Center funded by the U.S. Department of Energy, Office of Science, Basic Energy Sciences, under Award DE-SC0012702. 


\section{REFERENCES}

(1) Furukawa, H.; Cordova, K. E.; O’Keeffe, M.; Yaghi, O. M. Science 2013, 341, 974.

(2) Ferey, G. Chem. Soc. Rev. 2008, 37, 191.

(3) Horike, S.; Shimomura, S.; Kitagawa, S. Nat. Chem. 2009, 1, 695.

(4) Corma, A.; Garcia, H.; Llabres i Xamena, F. X. Chem. Rev. 2010, 110, 4606

(5) Lee, J.; Farha, O. K.; Roberts, J.; Scheidt, K. A.; Nguyen, S. T.; Hupp, J. T. Chem. Soc. Rev. 2009, 38, 1450.

(6) Gascon, J.; Corma, A.; Kapteijn, F.; Llabres i Xamena, F. X. ACS Catal. 2014, 4, 361.

(7) Farrusseng, D.; Aguado, S.; Pinel, C. Angew. Chem., Int. Ed. 2009, $48,7502$.

(8) Dhakshinamoorthy, A.; Alvaro, M.; Garcia, H. Catal. Sci. Technol. 2011, 1, 856.

(9) Ma, L. Q.; Abney, C.; Lin, W. B. Chem. Soc. Rev. 2009, 38, 1248.

(10) Yoon, M.; Srirambalaji, R.; Kim, K. Chem. Rev. 2012, 112, 1196.

(11) Manna, K.; Zhang, T.; Carboni, M.; Abney, C. W.; Lin, W. B. J. Am. Chem. Soc. 2014, 136, 13182.

(12) Fei, H. H.; Cohen, S. M. J. Am. Chem. Soc. 2015, 137, 2191.

(13) Gonzalez, M. I.; Bloch, E. D.; Mason, J. A.; Teat, S. J.; Long, J. R. Inorg. Chem. 2015, 54, 2995.

(14) Larabi, C.; Quadrelli, E. A. Eur. J. Inorg. Chem. 2012, 3014.

(15) Nguyen, H. G. T.; Schweitzer, N. M.; Chang, C. Y.; Drake, T. L.; So, M. C.; Stair, P. C.; Farha, O. K.; Hupp, J. T.; Nguyen, S. T. ACS Catal. 2014, 4, 2496.

(16) Mondloch, J. E.; Bury, W.; Fairen-Jimenez, D.; Kwon, S.; DeMarco, E. J.; Weston, M. H.; Sarjeant, A. A.; Nguyen, S. T.; Stair, P. C.; Snurr, R. Q.; Farha, O. K.; Hupp, J. T. J. Am. Chem. Soc. 2013, 135, 10294.

(17) Serna, P.; Gates, B. C. Acc. Chem. Res. 2014, 47, 2612.

(18) Cavka, J. H.; Jakobsen, S.; Olsbye, U.; Guillou, N.; Lamberti, C.; Bordiga, S.; Lillerud, K. P. J. Am. Chem. Soc. 2008, 130, 13850.

(19) Cliffe, M. J.; Wan, W.; Zou, X. D.; Chater, P. A.; Kleppe, A. K.; Tucker, M. G.; Wilhelm, H.; Funnell, N. P.; Coudert, F.-X.; Goodwin, A. L. Nat. Commun. 2014, 5, 4176.

(20) Vermoortele, F.; Bueken, B.; Le Bars, G.; Van de Voorde, B.; Vandichel, M.; Houthoofd, K.; Vimont, A.; Daturi, M.; Waroquier, M.; Van Speybroeck, V.; Kirschhock, C.; De Vos, D. E. J. Am. Chem. Soc. 2013, 135, 11465.

(21) Planas, N.; Mondloch, J. E.; Tussupbayev, S.; Borycz, J.; Gagliardi, L.; Hupp, J. T.; Farha, O. K.; Cramer, C. J. J. Phys. Chem. Lett. 2014, 5, 3716.

(22) Bhirud, V. A.; Uzun, A.; Kletnieks, P. W.; Craciun, R.; Haw, J. F.; Dixon, D. A.; Olmstead, M. M.; Gates, B. C. J. Organomet. Chem. 2007, 692, 2107.

(23) Zhao, Y.; Truhlar, D. G. J. Chem. Phys. 2006, 125, 194101.

(24) Metz, B.; Stoll, H.; Dolg, M. J. Chem. Phys. 2000, 113, 2563.

(25) Weigend, F. Phys. Chem. Chem. Phys. 2006, 8, 1057.

(26) Weigend, F.; Ahlrichs, R. Phys. Chem. Chem. Phys. 2005, 7, 3297.

(27) Cossi, M.; Rega, N.; Scalmani, G.; Barone, V. J. Comput. Chem. 2003, 24, 669.

(28) Perdew, J. P.; Burke, K.; Ernzerhof, M. Phys. Rev. Lett. 1996, 77, 3865.

(29) Kresse, G.; Furthmuller, J. Phys. Rev. B 1996, 54, 11169.

(30) Kresse, G.; Hafner, J. Phys. Rev. B 1994, 49, 14251.

(31) Kresse, G.; Hafner, J. Phys. Rev. B 1993, 47, 558.

(32) Kresse, G.; Furthmuller, J. Comp. Mater. Sci. 1996, 6, 15.

(33) Lu, J.; Serna, P.; Aydin, C.; Browning, N. D.; Gates, B. C. J. Am. Chem. Soc. 2011, 133, 16186.

(34) Miessner, H. J. Am. Chem. Soc. 1994, 116, 11522.

(35) Uzun, A.; Bhirud, V. A.; Kletnieks, P. W.; Haw, J. F.; Gates, B. C. J. Phys. Chem. C 2007, 111, 15064.

(36) Wu, H.; Chua, Y. S.; Krungleviciute, V.; Tyagi, M.; Chen, P.; Yildirim, T.; Zhou, W. J. Am. Chem. Soc. 2013, 135, 10525.

(37) Bonati, F.; Ugo, R. J. Organomet. Chem. 1968, 11, 341.

(38) Lu, J.; Aydin, C.; Browning, N. D.; Gates, B. C. Langmuir 2012, $28,12806$.
(39) Ogino, I.; Chen, C. Y.; Gates, B. C. Dalton Trans. 2010, 39, 8423.

(40) Delgado, M.; Santini, C. C.; Delbecq, F.; Baudouin, A.; De Mallmann, A.; Prestipino, C.; Norsic, S.; Sautet, P.; Basset, J.-M. J. Phys. Chem. C 2011, 115, 6757.

(41) Williams, L. A.; Guo, N.; Motta, A.; Delferro, M.; Fragala, I. L.; Miller, J. T.; Marks, T. J. Proc. Natl. Acad. Sci. U.S.A. 2013, 110, 413.

(42) Alecu, I. M.; Zheng, J. J.; Zhao, Y.; Truhlar, D. G. J. Chem. Theory Comput. 2010, 6, 2872.

(43) Hirshfeld, F. L. Theor. Chem. Acc. 1977, 44, 129.

(44) Mulliken, R. S. J. Chem. Phys. 1955, 23, 1833. 